\title{
Role orientation and organizational strategy among policy professionals in civil society
}

\author{
Joanna Mellquist ${ }^{1}{ }^{\circledR}$
}

Accepted: 12 December 2021 / Published online: 27 January 2022

(c) The Author(s) 2021

\begin{abstract}
How does hiring of policy professionals, to do the policy work of civil society organizations, impact the organizations that hire them? Policy professionals constitute a growing group of actors who populate many interest groups, working with advocacy and influencing public policy. As a group they comprise various types of professionals, displaying different backgrounds, identities and motivations. By analyzing individual policy professionals, asking questions about their identity and motivation to work with advocacy, and then through ethnographical observations following their work, this article contributes to the understanding of how policy professionals' backgrounds and professional identities are connected to organizational strategies and the process of professionalization. In so doing, it sheds new light on the dynamics of policy production and what professionalization of politics looks like in civil society. The article proposes a categorization of policy professionals' role orientations in civil society as policy scholars, policy lobbyists, policy communicators and policy activists. This conceptualization is of analytical value, because the balance between these categories affects dynamics within organizations and the work they do in relation to advocacy and policy, in tandem with their legitimacy.
\end{abstract}

Keywords Role orientations · Civil society $\cdot$ Advocacy $\cdot$ Policy professionals · Strategy

\section{Introduction}

How does hiring professionals, to do the policy work of civil society organizations (CSOs), impact the organizations that hire them? Scholars have noticed how professionalization of politics combined with increasing political complexity, including a mediatization of political life, has created a new political landscape (e.g., Svallfors 2020; Nothhaft 2017; Rhodes 2011; Ullström 2011; Johansson and Nygren 2019;

Joanna Mellquist

joanna.mellquist@sh.se

1 Södertörn University, Huddinge, Sweden 
Trapp and Laursen 2017). For civil society, these changes, together with professionalization and institutionalization of civil society (e.g., Lang 2013; Hwang and Powell 2009) whereby interest groups, CSOs and political parties have lost members (e.g., Putnam 2000; Skocpol 2003; von Essen 2019; Vogel et al. 2003; Amnå 2008; Harding 2012; Ahrne and Papakostas 2003 2014), have created a new field of work where professionals have taken on important roles in producing advocacy and policy content. Policy professionals constitute a growing group of actors who populate many interest groups, working with advocacy and influencing public policy; this group has mainly been studied in relation to public policy, think tanks and lobbyism (Garsten et al. 2015; Svallfors 2020; Svallfors 2017; Tyllström 2019; Sörbom 2018). The aim of this article is, however, to study what it means for civil society and member organizations to hire these professionals to do the policy work, and the consequence for professionalization in the field. It, therefore, contributes both to the literature on professionalization in civil society and to nuancing the research on policy professionals in general.

Professionalization of civil society, describing the process of nonprofit organizations becoming business-like and the tension between managerialism and volunteering, has been well studied in the social sciences (e.g., Salamon 1999; Skocpol 2003; Sanders and McClellan 2014; Eikenberry and Kluver 2004; Maier et al. 2016; Saurugger 2012; Maier and Meyer 2011; Kreutzer and Jäger 2011; Heylen et al. 2020; Lang 2013). Studies have also analyzed a variation of professionals and what they bring in the form of professionalization; see, for example, Hwang and Powell's (2009) contribution on professionalized staff integrating professional and managerial ideas into interest organizations. Scholarly attention has often been put on the educational background of leaders and managerial staff; less is, however, known about policy professionals, these 'experts' working directly with policy, and their consequence for civil society (Suarez 2011; Saurugger 2012; Jutterström et al. 2018).

The study of policy professionals in civil society is important because of the group's vast influence over advocacy, policy and strategy. By interviewing and following these professionals over a few years, this article analyzes role orientations and strategy in policy teams working at professionalized CSOs with a high level of organizational capacity. Following Albereda's understanding, '[o]rganizational capacity relates to those organizational elements that enable groups to act in an efficient and professional manner while internally generating expertise-based information' (Albareda 2020: 489).

The analysis draws on ethnographic data and 38 interviews with policy professionals working at 22 CSOs from Sweden, Latvia and the Netherlands. By analyzing role orientations among policy professionals in civil society, the article provides insights into the dynamics of policy production and what professionalization of politics looks like in civil society, raising two questions:

- What role orientations do policy professionals working within civil society organizations display?

- How do these roles affect strategies of these CSOs? 
In the first part of the paper, I review relevant academic literature on strategy and professionalization in civil society. Next, I propose some theoretical dimensions and earlier conceptualization of the field of policy professionals. The third part concerns the methodologies used for the study. The fourth section presents findings, focusing on the role orientation of policy professionals and their connection to strategy. The article ends with a discussion on how these findings can be understood in relation to professionalization of civil society.

\section{Professionalization and strategy in civil society}

Professionalization of civil society organizations has been well studied in the social sciences (e.g., Wilensky 1964; Skocpol 2003; Hwang and Powell 2009; Saurugger 2012; Heylen et al. 2020; Lang 2013). Most of these studies suggest that professionalization, that is, having employed experts in charge (Salamon 1999), decreases internal democracy in CSOs, leading to a potential loss of its function as a school of democracy in the Tocquevillian sense. The study of leaders and paid managerial staff in CSOs shows that professionalization and formalization affect the structure and maintenance of CSOs and their strategies; the more professionalized, the more division of labor is likely to be found (Staggenborg 1988: 590; Suarez 2011). Recent scholarship has, though, noted that hiring professionals does not always have to be associated with loss of democratic values; rather, it could facilitate membership influence (Heylen et al. 2020). A professionalized organization is here understood as containing three important features; autonomy, centralized structures and functional differentiation with professionalized staff dedicated to specific tasks at the headquarters (Albareda 2020: 492). This type of professionalization is, however, not only an endogenous process, emerging from a desire for effectivization, but also something pushed for from outside; expected by tax authorities and funding organizations (Lang 2013: 75; Hwang and Powell 2009).

Intending to answer the question of what hiring employees with a particular role orientation means for an organization's overall functioning and advocacy strategies, this section reviews earlier research that has investigated strategies and institutional logics connected to professional staff. Most research on civil society strategy, however, focuses on strategy at an organizational level, overlooking the agency of policy professionals. As Christensen (2017) demonstrates, with the example of economists within the state, focusing on the recruitment and the identity of employed experts has the potential to reveal how political outcomes can be interconnected between specific groups within the organization (Christensen 2017). In this regard, research on boundary crossing, skills and abilities among lobbyists, and the revolving door phenomenon that covered the individual professional's role in policy production, is of importance (e.g., Selling 2021; Holyoke et al. 2015; Timmermans 2015; Tyllström 2013; Lindgren and Wåhlin 2001), indicating that experience, communication strategies and personality play a role when individuals work with policy (Holyoke et al. 2015); however, not only skills but individuals are transformed as they travel between organizations and institutional fields (Tyllström 2019). 
Important attempts to analyze this category of professionals have pointed toward two major categories, those working to produce arguments and those working to get the message out: hacks and wonks (Medvetz 2012), or thinkers and doers (fixare och klurare, my translation, Garsten et al. 2015). Within this the group of doers, communicators and spin doctors have been analyzed as important carriers of media logics, bringing these ideas to civil society (Quinn 2012; Grafström et al 2015; Trapp and Laursen 2017). Within trade unions, professionals have been studied in a historical perspective, investigating relationships between professionals, experts and intellectuals (Hellberg 1997: 24; Wilensky 1956). Drawing on earlier research in this field, this article analyzes this group of experts as a field of policy professionals with varying role orientations and varying impacts on the production of policy and strategies at their organizations, contributing to a more nuanced portrayal of the group of policy professionals.

Scholars have used a variety of terms to define strategy and policy engagement of CSOs (e.g., Johansson et al. 2019; Grossmann 2012; Binderkrantz 2005; Halpin and Fraussen 2017; Albareda 2020). Some scholars distinguish between insider and outsider groups using different strategies (e.g., Grant 2000, 2004; Maloney et al. 1994). Insider strategies entail direct contact with policymakers, whereas outsider strategies entail media campaigns and mobilization of members. This division has been challenged by the understanding that most political groups use both strategies (e.g., Beyers 2004; Binderkrantz 2005; Trapp and Laursen 2017). Lately, strategies connected to digital advocacy and social media, and hence, communicators, have also arisen as a field of research (Brady et al. 2015; Johansson and Scaramuzzino 2019). Other scholars have noted the importance of access, informational lobbying by interest groups, and particularly, expert information (Binderkrantz et al. 2017; Flöthe 2019; Nownes and Newmark 2016). Regarding these later strategies, it has been noted that policymakers are in need of specific information, which CSOs can provide, at the same time as CSOs are in need of access to policymakers (Binderkrantz et al. 2017). This creates resource dependency, where information becomes a source of influence (Flöthe 2019: 168).

To sum up, in order to successfully attain policy influence, CSOs need a variety of specialized professionals generating expertise, each focused on different strategies-inside, outside, expert information and member engagement. This article connects these strategies to varying role orientations among the policy professionals studied in this paper.

\section{Conceptualization of the policy professional field}

The literature on policy professionals is still an emerging field, and policy professionals are still an understudied group in the European context. Heclo (1978) coined the term policy professionals in writing about issue networks in the American context. Garsten et al. (2015) introduced the term policy professionals in the Swedish context, by addressing the increasing professionalization of the Swedish political system. Studies have also focused on these actors in Latvia, the Netherlands, Ireland and Sweden to broaden and contextualize the understanding of these actors in 
a European context (Svallfors 2020). According to Svallfors, policy professionals are recruited and appointed to pursue policies within the state, lobbying organizations and civil society, and their particular skills are 'the ability to frame problems, to know the game and to access information' (Svallfors 2020: 121). Contrary to the terminology, policy professionals are as yet not understood as a profession (Brint 1994; Abbott 1988). They should rather be seen as a heterogeneous group, which nevertheless can be distinguished from other political actors by three criteria: 'they are employed, on a partisan basis, in order to ultimately affect policy' (Svallfors 2020: 3). Being employed, rather than elected to work with policy, means being hired to develop the organization's policy and advocacy strategies. Doing it on a partisan basis means working in accordance with one's ideological and political understandings, in contrast with a more neutral civil servant profile (see Svallfors 2020: 35-55). In practice, in the case of civil society, policy professionals are employed at the national office, working with policy ${ }^{1}$ and communication, providing support and information to management, boards and regional offices. They are responsible for producing internal policy documents within a CSO and/or attempting to change policy at a governmental level, lobbying politicians, creating spin based on the organization's statements or writing debate articles and so on. Common titles for the policy professionals at the organizations followed in the fieldwork undertaken for this project are as follows: Secretary, Investigator, Chief investigator, Analyst, Expert, Economist, Lawyer, Project manager, Lobbyist, Opinion maker, Press secretary, Informer, Communicator, Communication strategist, Policy expert, Policy advisor, Chief deputy and so forth.

Following Svallfors (2020), I understand policy professionals as political actors inhabiting a particular field, with specific rules, expectations and resources. Conceptualizing policy professionals as partakers of the field in which this group is investing enables analysis of how the field is interconnected to various institutional arenas and contexts, such as state and governmental authorities, the business sector, media, academia and civil society, illustrated in the figure below (cf. Medvetz 2012: 37) (Fig. 1).

Earlier research has mainly looked at policy professionals as a broad group of actors in all of these contexts. In this article, however, the focus is on policy professionals working in advocacy or member-based organizations in civil society, as illustrated above.

Policy professionals are understood as a boundary-spanning category, less bound to institutions, more loosely regulated at their workplace and with fewer credentials than other professionals (Svallfors 2020: 28). They are also seen as boundarycrossers who travel between fields and change organizations frequently (Lindgren and Wåhlin 2001). Changing fields is linked to a self-reflexive identity construction understood as a process; this process is important for the field of civil society, since many policy professionals in civil society during their careers move between organizations such as political parties and other CSOs (Selling and Svallfors 2019).

\footnotetext{
1 Policy here means 'a set of ideas, or a plan of what to do in a particular situation, that has been agreed officially by a group of people’ (Policy 2020).
} 


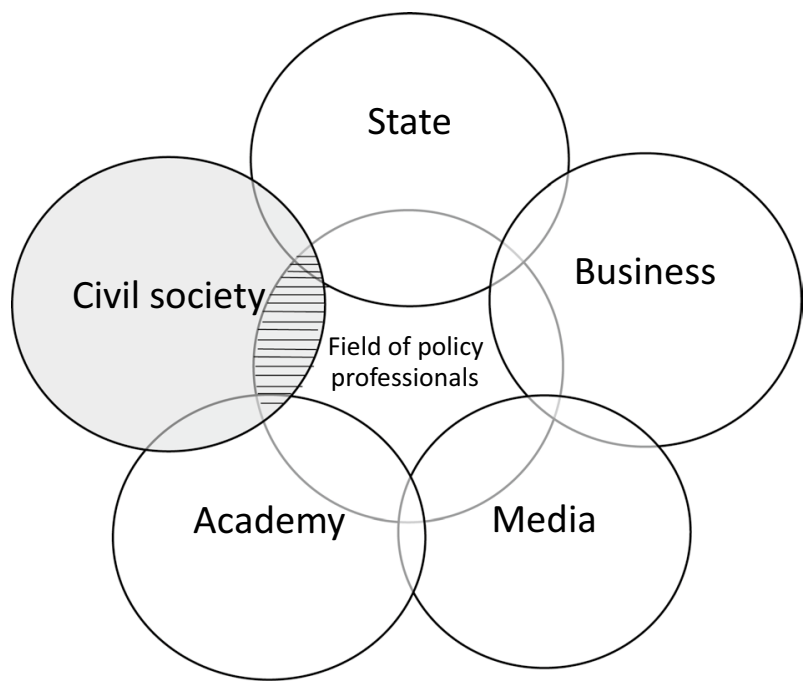

Fig. 1 The field in focus, intersecting other policy professional fields

In the intersection of fields, illustrated above, the logics of academia, civil society, politics, business and the media are important to varying degrees. This article connects the various role orientations of individual policy professionals to these logics. As developed in the section on findings, policy professionals draw on these logics differently, depending on their role orientation. Role orientation is here understood as a consequence of motivation, previous work, education and experience. The specific role orientation triggers the policy professionals to choose specific strategies that they are used to, like or are familiar with. The logic found in the varying institutional fields, which policy professionals are tied to, is understood as the underlying link between role orientations and strategies. When practices and ideas travel with these individuals, popular strategies assimilate and become implemented in new organizations, affecting civil society strategies at large (Strömbäck and Kiousis 2014; Falasca and Grandien 2017).

\section{Methodology and case selection}

This article builds on ethnographic data and 38 interviews with policy professionals working at 22 individual CSOs in Sweden, Latvia and the Netherlands. Starting with the Swedish sample, I contacted interviewees from an older study of policy professionals (Garsten et al. 2015), then added interviewees from medium to large advocacy-based CSOs such as unions and environmental organizations, and CSOs working with SRHR ${ }^{2}$ gender-based issues in Latvia, the Netherlands and Sweden. ${ }^{3}$

\footnotetext{
2 Sexual and reproductive health and rights.

3 Due to questions of confidentiality, both organizations and individuals have been guaranteed anonymity.
} 
The selection of interviewees was made with informants who work specifically with policy and who are well experienced in the field. I mainly searched for policy advisers, PR professionals, political secretaries and communications officers. Finding these informants was first accomplished by researching organizations' websites and by going through their LinkedIn social media profiles. Gaining access was hard in the case of Latvia and the Netherlands, whereas, with one exception, all informants asked in Sweden accepted the request. The case selection was therefore further complemented using a 'soft' snowballing technique, where the informants were asked to recommend influential policy professionals at their workplace or in their field. Not all types of policy professionals were interviewed across all organizations. However, judging by the organizations' web pages, all organizations in the selection can be characterized by high organizational capacity, meaning that they are skilled in generating policy expertise and a high level of access to decision-makers (see Albareda 2020).

The interviews from Sweden were conducted in Swedish, while those undertaken at CSOs in Latvia and the Netherlands were completed in English. For all interviews, a semi-structured questionnaire (Dexter 2006) was used. The national case selection was initially made to contrast the situation found in Sweden, a situation characterized by an ongoing change from a popular mass movement tradition, to a more pluralist and network-based political and civil society landscape (von Essen 2019; Svallfors 2020: 7). The intention of using comparative data from Latvia and the Netherlands was to comprehend the special features and what is distinct and what is universal within these processes of professionalization in Swedish civil society. The case selection was therefore strategically made, using two small European countries with distinct civil societies cultures, not to elaborate causal statement on the development in each country but to 'favor properly contextualized generalizations' (Katzenstein, 2003).

Compared to the Netherlands and Sweden, the field of CSOs in Latvia is characterized by a lower degree of active members and a generally weaker civil society (Howard 2003; Uhlin 2010). Latvian civil society is largely made up of small NGOs, but many organizations tend to have some staff, which indicates a quite professionalized civil society, run by strong leaders yet with little possibility to mobilize people (Huber 2011; Uhlin 2010: 844; Lindén 2008). The field of policy professionals is, however, significantly smaller; many NGOs struggle with funding, with the consequence of having professionals hired on a project basis, rather than in permanent policy teams. In the Netherlands, civil society has, compared to Latvia and to Sweden, well-developed relationships with governmental institutions, and civil society is expected to lobby and advocate for social change (Government of the Netherlands 2014; Wessel et al. 2020). The Netherlands is a country with a high density in the population of CSOs, citizen groups engaged in lobbying that have become important players in setting the agenda and portraying problems (Timmermans 2015). However, the analysis of the empirical data soon revealed that irrespective of these variations in the three contexts, the groups of policy professionals studied displayed quite similar characteristics regarding, for instance, professional backgrounds, identities and roles. In fact, the differences between the groups of policy professionals turned out to be of greater analytical importance than those pertaining to national differences. The material is therefore used as one, indicating variations within the 
group of policy professionals, and not for a comparative purpose based on national contrasts.

In addition to interviews, 80 hours of observation were completed in Sweden, shadowing (Czarniawska 2007) multiple policy professionals at work in three selected member-based advocacy organizations. The selection was made strategically with interviewees with whom I had good contact and who were to participate in larger advocacy events important for the fieldwork. The ethnographic data were gathered for 1 year, comprising a journal, meeting notes and field notes, which produced rich descriptions on expressed commitment and self-identification at work. These data are not displayed in the empirical chapter, but rather have informed the analysis and categorization. Both interviews and shadowing gave opportunities to study how these professionals affect the organizations' overall strategy, their focus on inside or outside lobbying, and their relationship to peers, members and elected representatives. The shadowing allowed me to observe these connections, not only to ask about them, which was important to overcome any possible attitudinal fallacy (Jerolmack and Khan 2014).

All interviews and field notes were transcribed and coded, using a technique of provisional coding, which later was adopted as core codes and categories (Layder 1998). The analytical process has been inspired by an abductive approach, going back and forth between theory and material throughout the research process (Meyer and Lunnay 2013).

The empirical analysis led to the identification of four conceptual role orientations based on the interviewees' self-identification, education, previous careers, background and motivation: policy scholar, policy lobbyist, policy communicator and policy activist. Following earlier research, insider and outsider strategies were connected to these role orientations: Lobbying and insider strategies were operationalized as contacting politicians and state officials. Scholarly roles included providing expert information, for example, by answering government commission premises and participating in panels, reference groups and so forth. Voice and advocacy strategies were conceptualized as media or social media strategies. Lastly, policy activists mobilized members through, for example, the use of protest, demonstrations and petitions (Beyers 2004; Johansson et al. 2019) (Table 1).

These role orientations should be seen as ideal types (Weber 1994) and not as essential categories. Some policy professionals map very well onto only one of these orientations, but some would find two or more orientations useful, depending on their position and particular task at the organization, for example, working with both knowledge production and direct lobbying. These ideal types were constructed in the intersection of data, theory and earlier research, designed to differentiate patterns in a wide and diverse group of professionals.

\section{Findings}

The next section describes the interviewees based on their role orientations and motivations for working in civil society, moving on to show how these particular role orientations impact organizational strategies. 


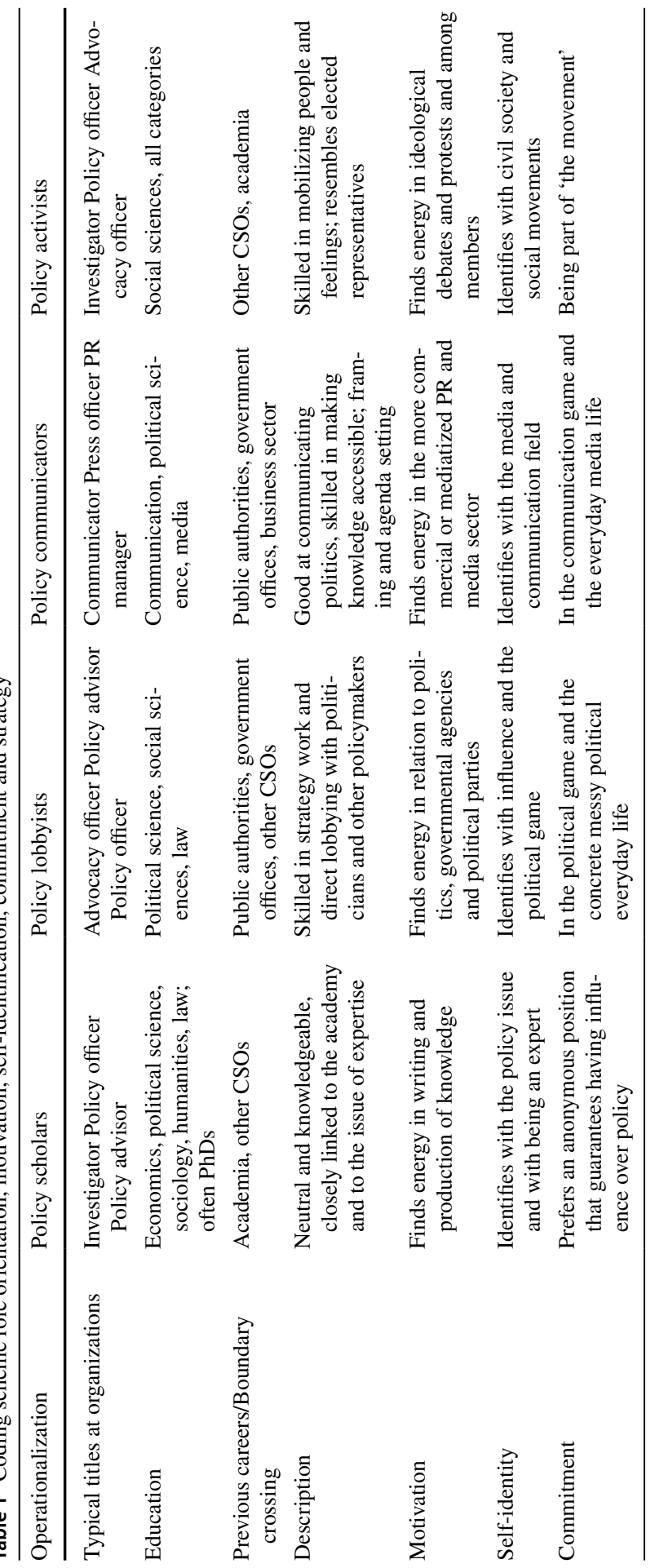

. 가의 


\section{Policy scholars}

The first role orientation is termed 'policy scholar.' The interviewees displaying this orientation work with in-depth knowledge production and use insider strategy on diverse policy issues at the organizations where they are employed. These policy professionals identify with knowledge production and academia, and often have the title of investigator, policy officer or expert. They prefer to write and think rather than do the 'dirty work' of contact, communication and meetings.

For me, the most fun is to write, but as soon as you work somewhere you need to attend all these meetings, all the time. There are so many other things that need to be handled. (J-9 at Swedish political party)

A key characteristic amongst policy scholars, thus, is the preference of not being at the forefront of the organization. Rather, they are engaged in writing, formulation and policy change, and prefer to work in the shadows of other professionals. Within this category of professionals, and these individuals, they see themselves as part of a layer in civil society working with academic knowledge production.

One of the fundamental questions asked in the interview was how they identify themselves professionally:

I was at a conference last week that dealt with my policy issues. There were people who worked as experts in the ministries, experts from the insurance fund, researchers, and some different people from organizations. Then I felt at home! (J-5 at Swedish trade union)

I'm working with international and European law. And working with this is either you're an academic, a lector at the university or at the government. But you are like a theory-based person. (J-23 at Latvian trade union)

These kinds of statements demonstrate how policy scholars enjoy having expert knowledge and being sought out because of this expertise. Most policy scholars also strongly identify with what is referred to as 'their policy issue,' being an expert in that subfield. Some of the experts identify more as researchers in their field, like economists or political scientists. Many policy scholars have a higher education degree, and their connection to academia is strong. Academia is also an important counterpart that they identify with, turn to and want to be acknowledged by.

Policy scholars resemble Wilensky's (1956) 'facts and figures man,' who has specialized training in statistics, social sciences and economy. They are less into human resources and more into framing subjects through figures, 'skilled in the production of quick and simple answers to complex questions' (Wilensky 1956: 42). The loyalty of this group is first of all to the specific policy field in which they are active, for example, to gender equality or climate change. They are not particularly attached to persons or organizations, as long as they can work in this particular policy field.

These particular policy professionals are at their best when they write new proposals, reports or legislative amendments. As policy scholars, this group of CSO professionals is not so much involved in direct lobbying or media strategies; they derive their energy from writing and working with knowledge development where 
they do not need to deal with the social challenges of direct lobbying. Hence, insider strategy and the production of expert information are preferred strategies, enjoying a more anonymous position within organizations that still guarantees their influence over policy.

\section{Policy lobbyists}

The second role orientation is that of the 'policy lobbyist,' constituting a group that enjoys working with policy change and influence, regardless of the organization, as long as the subject matter is interesting, and they have a prominent role in it. Policy lobbyists are good at strategies that involve direct access to policymakers, in direct lobbying with politicians and other policymakers. They might write reports now and then, but they are more into having contacts, monitoring policy fields and debates, and contributing to and writing up strategies for the organizations. Compared with other role orientations, the policy lobbyist identifies more with 'lobbying,' getting the work done:

Interviewer: What would you say you identify with as a professional category, if someone asks?

Lobbyist.

Interviewer: Lobbyist?

Yes, it has traditionally been a nasty word - that's why I say it like this: on my business card it says political expert, so that is what I am. But I also work with influence. So, to state it clearly, I'm a lobbyist. (JCS-19 at Swedish SRHR organization)

Policy professionals displaying this role orientation identify with influence, change and direct lobbying. If policy scholars are concentrated on writing reports, policy lobbyists make sure the message reaches the right people, directly.

Policy lobbyists have typically worked in many political spheres, such as political parties, governmental offices or other authorities. Among this group both senior and junior colleagues seemed to have prominent and influential positions within their organizations. They find their motivation in working with direct policy change, rather than working in a specific policy area. When asked what feels most fulfilling about their work, the standard answer is to get someone to do what you want them to do:

Okay. I love getting results. So, when I've been lobbying for something, and it works, that's when I'm like, yes, I did well.

Interviewer: Can you give an example?

Let me think. Oh. It can be something really easy, such as when I'm trying to get a politician to ask parliamentary questions about something, and the politician does this. That makes me really happy. Yeah. Or I ask them to bring something up during a debate and they do it. The best thing is obviously when a politician brings something up during a debate, and then policy actually gets changed, and later on, the practice gets changed. (JCS-42 at Dutch SRHR organization) 
Characteristic of policy lobbyists is that they know how the system works and want to be part of an organization because it is influential. Merely being part of civil society is not enough.

Now I know that I want to work with political influence and policymaking. Earlier, I was more into working with campaign and advocacy. Now, I'm pretty sure I don't want to do that. [Laughter] When 'they' make an impact, they have a communications person who runs campaigns on various issues. We meet politicians, produce things. We work a lot less - it sounds a bit shady when you say it - but, less visibly.

(JCS -28 at Swedish temperance organization)

Policy lobbyists are like the 'contact men,' experts who also manipulate thoughts and feelings of decision-makers, as termed by Wilensky (1956: 61). Compared to scholars, and communicators, these policy professionals use access strategies and have face-to-face contact with important political players. Importantly, policy lobbyists work more closely with their principals, for instance, by accompanying them to meetings with officials, than do other policy professionals. Policy lobbyists are also strongly motivated by working with strategies to access both outside decision-makers and upper echelons of the CSO where they work. They want to be close to power, working closely with management and the board. Indeed, we may say that they lobby both externally and internally.

\section{Policy communicators}

The third type of role orientation is termed 'policy communicator.' As the designation indicates, policy professionals displaying this orientation are good at communicating politics and getting the message out to the public, either in written drafts, through media or by framing other actors' statements or ideas. Policy communicators are hired as 'communicators' — as 'PR' and 'media' experts—or as advocacy and policy officers, and their strategies are connected to making knowledge accessible, handling media contacts, framing and agenda setting. They are at their best when they communicate and organize other people's ideas. Policy communicators are also skilled in writing up strategies, often based on knowledge from policy scholars, and just as the policy scholar, they hardly ever act as the face of the organization when meeting other representatives outside the CSO. On the possibility of working as a politician, a policy communicator describes her identity like this:

I think I'm a typical 'behind the scenes person'.... If I have an idea and I then hear someone talk about it as their idea, I often feel like, 'Shit, that's good!' rather than 'Now you took my idea.'(JCS-27 at Swedish trade union organization)

Instead of being in the spotlight, policy communicators plan and organize what other actors or initiators should say or write, and how to say it to achieve success. 
Both policy communicators and policy lobbyists display a specific salient attraction to power and influence. These policy professionals could work anywhere (within the span of their values), as long as they are in the thick of policy change. What motivates policy communicators and lobbyists the most is typically expressions of policy success: fomenting headlines, planting debate articles or successfully reaching out with campaigns on a particular policy topic. Policy communicators find their satisfaction in the 'political game' and the concrete, messy political everyday life. A policy communicator who previously had worked closely with a minister in government stresses the importance of actual influence:

I want to work in such an environment where something actually happens! I'm engaging myself in something, not just because I want to sit and count hits on any press release; I want it to lead somewhere. I think it's worthless if I do not get into it and feel that what I do has an effect. (JCS-18 at Swedish environmental organization)

This policy communicator was employed at this particular organization because, according to him, things actually happen there. He had previously worked at the governmental office. Being part of the civil society sphere was never an end in itself. Now working at this $\mathrm{CSO}$, he recognizes the potential of civil society and the central position and influence he has while working here. Policy communicators are, as they have been trained to be, skilled in framing expert information, and they use strategies connected to both inside and outside strategy, planning both media campaigns and communication with policymakers. Moreover, policy communicators, rather than lobbyists, have a particular mediating function, adding to the organization's reputation as 'respectable' and 'responsible' by encouraging the CSOs principal to 'play it safe' in relation to the public (Wilensky 1956: 78). However, both policy communicators and policy lobbyists are skilled in polishing the ideology of organizational leadership. Communicators and lobbyists have connections in the policy field at large and handle relations between the leaders and the world outside the CSO (Wilensky 1956: 61).

\section{Policy activist}

The fourth role orientation, 'the policy activist,' is more connected to civil society and social movements, and is often closely linked to politicians and elected representatives. The professionals expressing this orientation identify as members of a civil society or as social movement activists, and it is from this belonging that they derive their strategies. The sense of being part of something larger, which all policy professionals desire, is dominating for this group who are skilled in ideology and mobilizing members:

I work in a people's movement, an interest organization. Not only because I have a knowledge base and I have academic education.... It is also assumed that I share, as it is called when we are employed, the values of this social movement. In some sense, it is the reason why my employer hired me, that 
we believe in some form of common idea. That's why I'm different from the civil servants. So, in that sense, I'm not a technocrat in the way they are, but I work on a mission based on an ideological mission, one could say. (J-6 at Swedish trade union organization)

In this statement, the policy activist emphasizes the value found within this organization. He was employed because of a connection to the movement, and this gives him an ideological mission. He identifies with the mission not only as a civil servant. It is an ideological commitment, desired both by the employers and by the professional.

When asking about career choice, some policy activists say they have turned down employment offers from other organizations, which according to them would have been a better career choice with a higher salary, because they wanted to 'be a part of the chain that changes society.' Being part of social change is for policy activists more significant than having a career. In this, the role orientation of policy activists resembles that of the policy lobbyist, although the former most typically rejects the lobbyist identity. Policy activists may do similar work, but they assert that, in contrast to lobbyists, they do it for their members, 'for the people.'

Policy activists' motivations are commonly connected to moments of pride, doing some good for the larger community. When asked about career paths and incentives to work in CSOs, emotions are explicitly important.

I want to feel very much. I want to push.... I do this because I want to influence and change society. That's my motivation. So, just being some kind of service person who just will execute orders, that is not attractive. (J-11 at Swedish environmental organization)

The policy activist's idea of her/his influence is derived from having a background in the social movement, which is manifested in this response. The policy activists find motivation in and favor strategies connected to ideological debates, protests and mobilizing 'the movement.' Moreover, their motivation is associated with moral values. It includes a feeling of right and wrong, in this case, a sense of righteousness: they feel like good people. This feeling generates altruism; it is a feeling of solidarity, of wanting to defend the group or the cause they work for.

As outlined above, within the CSOs studied here we find four types of role orientations for the policy professionals. Irrespective of the three national contexts within which these policy professionals are active, they express the idea that we are not civil servants; we work with influencing society. However, policy professionals within CSOs exercise this influence from different angles and with strategies, as described in the next section.

\section{Strategies among policy professionals in civil society}

What does hiring employees with a particular role orientation mean for an organization's overall functioning and advocacy strategies? The four types of role orientations outlined above use and favor different strategies, summarized in the following (Table 2): 
Table 2 Role orientation and strategy

\begin{tabular}{lllll}
\hline Policy scholars & Policy lobbyists & $\begin{array}{l}\text { Policy communica- } \\
\text { tors }\end{array}$ & Policy activists \\
\hline Strategy & $\begin{array}{c}\text { Insider strategies, } \\
\text { expert information }\end{array}$ & $\begin{array}{c}\text { Insider strategies, } \\
\text { expert information, } \\
\text { access }\end{array}$ & $\begin{array}{l}\text { Insider strate- } \\
\text { gies, framing, } \\
\text { voice,outside } \\
\text { strategy }\end{array}$ & $\begin{array}{c}\text { Mobilizing members, } \\
\text { voice, expert infor- } \\
\text { mation }\end{array}$ \\
\hline
\end{tabular}

When placed in a central position within the organization, both senior and junior policy professionals have a vast influence in internal decision-making structures and procedures, with a high ability to influence decisions. The various role orientations of individual policy professionals are connected to these strategies, which in turn are embedded in logics and relationships with actors outside civil society. Figure 2 illustrates these logics connected to corresponding fields outside of the organization:

These are the types of fields to which policy professionals primarily turn, and whose logics they follow or are influenced by. For policy lobbyists, the contact and aspirations of policy work go in the direction of decision-makers within the state/government. It is this group that policy lobbyists aim to influence and to understand, and to which the policy lobbyists turn and compare themselves. They bring knowledge and logics from the political sphere to civil society. Policy communicators target the media, relate to journalists and are driven and influenced by media logics which they implement in civil society. For policy scholars, the academy is an obvious interlocutor to compare themselves to when working with policy documents, knowledge production or general policy influence. In strategic policy discussions, they rather anchor policy content in research, compared to lobbyists and communicators who are keener on using framing tactics. Policy activists relate to activist strategies found in the "movement' and anchor the organization in a civil society tradition.

Policy professionals relate to and travel between these various arenas, which is of consequence for their practices and strategies, and in turn for the organizations they work for (Trapp and Laursen 2017). This opens up possibilities for further professionalization, but also for conflicts among groups driven by discrepant role orientation. When engaging in strategic conversations, they will typically draw on separate logics, which entails the use of diverse strategies. To create an illustrative example including the four ideal types, it is possible to imagine a strategic meeting where the policy scholar would want to investigate the issue and write a report, the policy lobbyist would want to book a series of meetings with politicians and the policy communicator would propose a campaign, while the policy activist would propose gathering the members and making a protest.

One example of how tension between these professionals could create conflicts is caught in the statement below, where a policy scholar describes a sensation of being overruled by the management and communication unit in strategic decisions: 


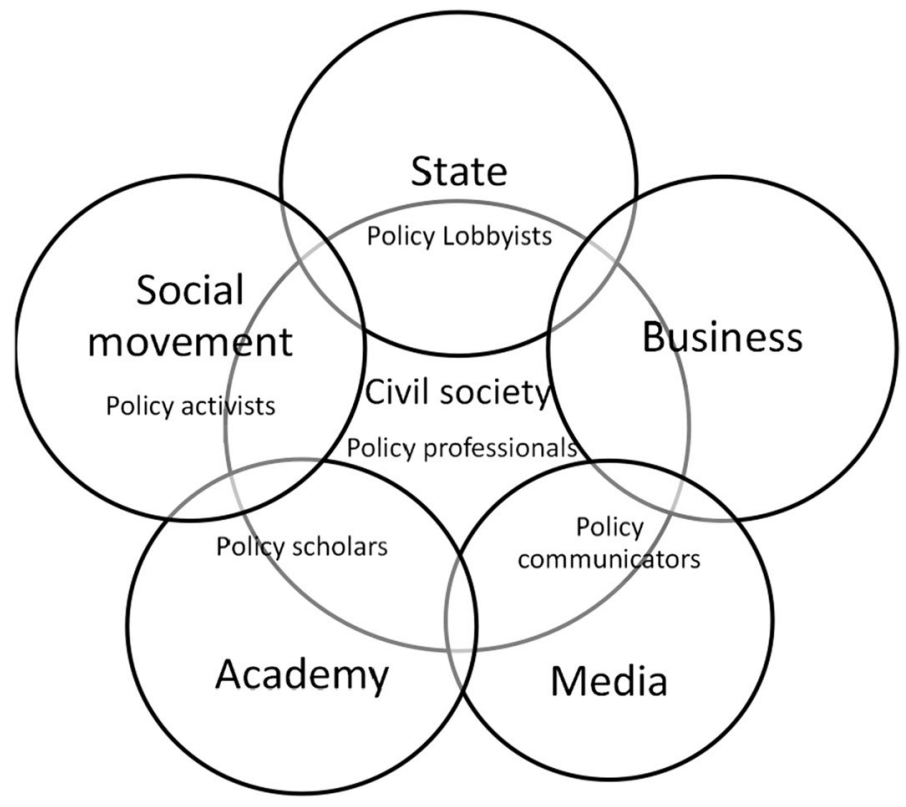

Fig. 2 Policy professionals' role orientation in civil society related to intersecting fields (Both policy lobbyists and communicators relate to and work more with the business logics than the others, but civil society policy professionals do not display any stronger relationship to the business sector. Therefore, this field is left empty in this figure)

It was really decided upon by the communication unit together with our secretary and the head of office. I found out when we were sitting in a meeting with the advertising agency who were helping us with this campaign. Of course, they had not thought about the difficulties that exist in this policy issue and, above all, what technical difficulties really.... (J-15 at Swedish Pensioners' Organization)

The policy scholar, responsible for the policy area of the campaign, was not heard when the campaigns were decided upon, creating a feeling of being overridden. This tension, in policy strategies and in how to get the message out, was recurrent in most interviews, as these actors are driven by different logics and have different motivations.

When moving between organizations and crossing boundaries, policy professionals bring their self-identification, strategy and motivation to these CSOs working with advocacy and policy agendas. Hence, identifying these role orientations is relevant for understanding the dynamics of professionalization in civil society. If one or the other group dominates, there may be consequences for the organization's strategies and policy interests, since these individuals become bearers of discrepant institutional logics, promoting certain strategies over others. As a boundary-spanning category of professionals, they become bearers of institutional logics: communicators bring media strategies and so on (Lindgren 
and Wåhlin 2001), and these concepts and ideas become translated and implemented (Grandien 2016), of consequence for the organization's strategies and for their legitimacy.

\section{Conclusions}

In this article, findings on policy professionals' role orientations suggest four different groups who all have strong but varying driving forces for influencing policy content: policy scholars, policy lobbyists, policy communicators and policy activists. The article hereby contributes to nuancing the research on policy professionals in general and the understanding of professionalization of civil society in particular, showing how striving for influential positions, creating knowledge, influencing policy or promoting actual societal change is a generic feature of these types of professionals working in CSOs. The material does not allow for solid generalizations; nevertheless, most organizations employ a communicator, but not all have employed a person with an activist background. Following the conflicts, visible in the material, an increase of communicators' and lobbyists' influence can be detected.

The specialization and role distribution among the four groups driven by diverse role orientations described in this article may produce more efficiency for CSO policy teams; it may, however, also create problems. In relation to earlier research on professionalization and the tension created when interest organizations develop business-like strategies (Sanders and McClellan 2014; Kreutzer and Jäger 2011), this article emphasizes the tension between strategic decisions connected to role orientations that may have consequences for the democratic development, and for the CSO's potential contribution to civic engagement. The functional differentiation (Albareda 2020) and professionalization of civil society, understood as employing more experts (Salamon 1999), could perhaps enhance the organizations' advocacy performance, and it does not necessarily have to decrease members' involvement and internal democracy (Heylen et al. 2020). This article, however, points specifically toward the importance of the types of policy professionals taking office within CSOs.

The loyalty, trust and commitment to the cause found among policy activists functions as an anchor to the movement. Policy scholars' expertise is needed to provide the knowledge upon which these advocacy organizations work, and both policy lobbyists and policy communicators are needed to ensure that the organization is influencing both the public and policymakers. Nevertheless, the different role orientations develop and cultivate different interests and strategies, which runs the risk of hampering internal coherence of the organization. Too strong a separation between the role orientations could implicate problems in moving toward a common goal. This is the shape of policy professionalization of civil society. Professionalization up close is not merely about hiring someone to do the job of members, but whom the organization chooses to hire: a communicator, a lobbyist, an expert or an activist? 
The specific types of commitment, motivation and background the policy professionals bring to the organization matter to understanding the development of CSOs, and more specifically the nexus of organizational strategy and internal democracy processes. The recruitment and the identity of employed experts are connected to the organization's strategy and policy interests by the preferred strategies and logics that the individual policy professional is invested in. And depending on the balance of these professionals' role orientations, civil societies' ability to partake in public policy deliberations stands at risk in tandem with matters of legitimacy.

The selection of cases, with a high level of organizational capacity, creates limitations for the generalizability of these findings. In smaller, less resourceful organizations the relevance of these role orientations is limited. Further research suggests studying to what extent an organization is functionally differentiated, which role orientations are more prominent within the organization and how this affects advocacy work. Also of value to study is the variation between small and large organizations and between different fields within which organizations are active.

\section{Declarations}

Conflict of interests The author declares no potential conflicts of interest with respect to the research, authorship, and/or publication of this article.

Open Access This article is licensed under a Creative Commons Attribution 4.0 International License, which permits use, sharing, adaptation, distribution and reproduction in any medium or format, as long as you give appropriate credit to the original author(s) and the source, provide a link to the Creative Commons licence, and indicate if changes were made. The images or other third party material in this article are included in the article's Creative Commons licence, unless indicated otherwise in a credit line to the material. If material is not included in the article's Creative Commons licence and your intended use is not permitted by statutory regulation or exceeds the permitted use, you will need to obtain permission directly from the copyright holder. To view a copy of this licence, visit http://creativecommons.org/licen ses/by/4.0/.

\section{References}

Abbott, A.D. 1988. The system of professions: An essay on the division of expert labor. Chicago, IL: University of Chicago Press.

Ahrne, G., and A. Papakostas. 2003. Behövs medlemmarna? Sociologisk Forskning 3: 3-10.

Ahrne, G., and Papakostas, A. (2014) Organisationer, samhälle och globalisering: tröghetens mekanismer och förnyelsens förutsättningar. Lund: Studentlitteratur.

Albareda, A. 2020. Prioritizing professionals? How the democratic and professionalized nature of interest groups shapes their degree of access to EU officials. European Political Science Review 12 (4): $485-501$.

Amnå, E. (2008) Jourhavande medborgare: samhällsengagemang $i$ en folkrörelsestat. Lund: Studentlitteratur.

Beyers, J. 2004. Voice and access: Political practices of European interest associations. European Union Politics 5 (2): 211-240.

Binderkrantz, A.S. 2005. Interest group strategies: Navigating between privileged access and strategies of pressure. Political Studies 53: 694-715. 
Binderkrantz, A., H. Pedersen, and J. Beyers. 2017. What is access? A discussion of the definition and measurement of interest group access. European Political Science 16 (3): 306-321.

Brady, S., J. Young, and D. Mcleod. 2015. Utilizing digital advocacy in community organizing: Lessons learned from organizing in virtual spaces to promote worker rights and economic justice. Journal of Community Practice 23 (2): 255-273.

Brint, S.G. 1994. In an age of experts: The changing role of professionals in politics and public life. Princeton, NJ: Princeton University Press.

Czarniawska, B. 2007. Shadowing and other techniques for doing fieldwork in modern societies. Malmö: Liber.

Christensen, J. 2017. The power of economists within the state. Stanford, CA: Stanford University Press.

Dexter, L.A. 2006 [1969]. Elite and specialized interviewing. Colchester, UK: ECPR Press.

Eikenberry, A., and J. Kluver. 2004. The marketization of the nonprofit sector: Civil society at risk? Public Administration Review 64 (2): 132-140.

Falasca, K. and Grandien, C. 2017. Where you lead we will follow: A longitudinal study of strategic political communication in election campaigning. Journal of Public Affairs 17 (3): e1625.

Flöthe, L. 2019. Technocratic or democratic interest representation? How different types of information affect lobbying success. Interest Groups and Advocacy 82: 165-183.

Garsten, C., Rothstein, B. and Svallfors, S. (2015) Makt utan mandat: de policyprofessionella i svensk politik. 1. uppl. Stockholm: Dialogo.

Government of the Netherlands. 2014. 'Dialogue and dissent': Strategic partnerships for lobby and advocacy. Policy Framework. https:/www.government.nl/topics/grant-programmes/documents/ regulations/2014/05/13/policy-framework-dialogue-and-dissent

Grafström, M., K. Windell, and P. Petrelius Karlberg. 2015. Mediatization of civil society organizations: (De) legitimation of the Swedish Red Cross. Journal of Civil Society 11 (3): 227-241. https://doi. org/10.1080/17448689.2015.1057415.

Grandien, C. (2016) Strategic Communication Found in Translation: Practices, Practitioners and Perceptions. Doctoral thesis. Mid Sweden University.

Grant, W. 2000. Pressure groups and british politics. London: Macmillan.

Grant, W. 2004. Pressure politics: The changing world of pressure groups. Parliamentary Affairs 57 (2): 408-419.

Grossmann, M. 2012. The Not-So-Special Interests: Interest Groups, Public Representation, and American Governance. Stanford, CA: Stanford University Press.

Harding, T. (2012) Framtidens civilsamhälle: underlagsrapport 3 till Framtidskommissionen.

Halpin, D.R., and B. Fraussen. 2017. Conceptualising the policy engagement of interest groups: Involvement, access and prominence. European Journal of Political Research 56 (3): 723-732.

Heclo, H. 1978. Issue networks and the political establishment. In The new American political system, ed. K. Anthony, 87-124. Washington, DC: The American Enterprise Institute.

Hellberg, I. (1997) Det fackliga förtroendet: en studie av ombudsmän och experter 1950-1991. Stockholm: Atlas.

Heylen, F., E. Willems, and J. Beyers. 2020. Do professionals take over? Professionalisation and membership influence in civil society organisations. VOLUNTAS: International Journal of Voluntary and Nonprofit Organizations 31 (6): 1226-1238.

Holyoke, T., H. Brown, and T. LaPira. 2015. Learnable skills, or unteachable instinct? What can and what cannot be taught in the lobbying profession. Interest Groups \&amp; Advocacy 4: 7-24. https://doi. org/10.1057/iga.2014.27.

Howard, M. 2003. The weakness of civil society in post-communist Europe. New York, NY: Cambridge University Press.

Huber, S. (2011) Citizens Participation in Latvia: Still a Long Road to Go? Forschungspapiere 'Probleme der Öffentlichen Verwaltung in Mittel- und Osteuropa' (12) Universität Potsdam.

Hwang, H., and W. Powell. 2009. The rationalization of charity: The influences of professionalism in the nonprofit sector. Administrative Science Quarterly 54 (2): 268-298.

Jerolmack, C., and S. Khan. 2014. Talk is cheap: Ethnography and the attitudinal fallacy. Sociological Methods and Research 43 (2): 178209.

Johansson, K.M., and G. Nygren, eds. 2019. Close and distant: Political executive: Media relations in four countries. Göteborg: Nordicom.

Johansson, H., and G. Scaramuzzino. 2019. The logics of digital advocacy: Between acts of political influence and presence. New Media and Society 21 (7): 1528-1545. 
Johansson, H., R. Scaramuzzino, and M. Wennerhag. 2019. Social movements and interest groups compared: How organisational type matters for explaining Swedish organisations' advocacy strategies. Partecipazione E Conflitto 12 (2): 353.

Jutterström, M, Segnestam Larsson, O., Zetterström, S. and Hedlin, D. (2018) Anställd i det svenska civilsamhället: Engagemang, ansvar och delaktighet.

Kreutzer, K., and U. Jäger. 2011. Volunteering versus managerialism: Conflict over organizational identity in voluntary associations. Nonprofit and Voluntary Sector Quarterly 40 (4): 634-661.

Lang, S. 2013. NGOs, civil society, and the public sphere. Cambridge: Cambridge University Press.

Layder, D. 1998. Sociological Practice: Linking Theory and Social Research. London: Sage.

Lindén, T. 2008. Explaining civil society core activism in post-Soviet Latvia. Doctoral dissertation. Södertörn Political Studies, Stockholm Studies in Politics.

Lindgren, M., and N. Wåhlin. 2001. Identity construction among boundary-crossing individuals. Scandinavian Journal of Management 17 (3): 357-377.

Maloney, W.A., J. Grant, and A.M. McLaughlin. 1994. Interest groups and public policy: The insider/ outsider model revisited. Journal of Public Policy 14 (1): 17-38.

Maier, F., M. Meyer, and M. Steinbereithner. 2016. Nonprofit organizations becoming business-like: A systematic review. Nonprofit and Voluntary Sector Quarterly 45 (1): 64-86.

Maier, F., and M. Meyer. 2011. Managerialism and beyond: Discourses of civil society organization and their governance implications. VOLUNTAS: International Journal of Voluntary and Nonprofit Organizations 22 (4): 731.

Medvetz, T. 2012. Think Tanks in America. Chicago, IL: University of Chicago Press.

Meyer, S.B., and B. Lunnay. 2013. The application of abductive and retroductive inference for the design and analysis of theory-driven sociological research. Sociological Research Online 18 (1): 1-11.

Nownes, A.J., and A.J. Newmark. 2016. The information portfolios of interest groups: An exploratory analysis. Interest Groups \& Advocacy 5 (1): 57-81.

Nothhaft, C. 2017 Moments of lobbying: An ethnographic study of meetings between lobbyists and politicians. Doctoral dissertation. Örebro: Örebro högskola.

Policy. 2020. Cambridge English Dictionary. Retrieved from https://dictionary.cambridge.org/dictionary/ english/policy

Putnam, R.D. 2000. Bowling alone: The collapse and revival of American community. New York, NY: Simon and Schuster.

Quinn, T. 2012. Spin doctors and political news management: A rational-choice 'exchange' analysis. British Politics 7 (3): 272-300.

Rhodes, R.A.W. 2011. Everyday life in British Government. Oxford, UK: Oxford University Press.

Salamon, L. 1999. The nonprofit sector at a crossroads: The case of America. VOLUNTAS: International Journal of Voluntary and Nonprofit Organizations 10 (1): 5-23.

Sanders, M., and J. McClellan. 2014. Being business-like while pursuing a social mission: Acknowledging the inherent tensions in US nonprofit organizing. Organization (london, England) 21 (1): 68-89.

Saurugger, S. 2012. The professionalization of EU's civil society: A conceptual framework. In New Participatory Dimensions in Civil Society: Professionalization and Individualized Collective Action, 69-83. London: Routledge.

Selling, N. 2021. The long shadow of lobbying: Ideational power of lobbying as illustrated by welfare profits in Sweden. Interest Groups \&amp; Advocacy 10: 47-67. https://doi.org/10.1057/ s41309-021-00111-6.

Selling, N., and S. Svallfors. 2019. The lure of power: Career paths and considerations among policy professionals in Sweden. Politics and Policy 47 (5): 984-1012.

Skocpol, T. (2003) Diminished Democracy: From Membership to Management in American Civic Life. The Julian J. Rothbaum Distinguished Lecture Series, 8. Norman, OK: University of Oklahoma Press.

Staggenborg, S. 1988. The consequences of professionalization and formalization in the pro-choice movement. American Sociological Review 53 (4): 585-605.

Strömbäck, J., and S. Kiousis. 2014. Strategic political communication in election campaigns. In Political communication, ed. C. Reinemann, 249-266. Berlin, Germany: Walter de Gruyter.

Svallfors, S. 2017. Knowing the game: Motivations and skills among partisan policy professionals. Journal of Professions and Organization 4 (1): 55-69.

Svallfors, S. 2020. Politics for hire: The world and work of policy professionals. Cheltenham, UK: Edward Elgar. 
Sörbom, A. 2018. Från snack till organiserade nätverk: Om tankesmedjors arbete för att värva andra för sina idéer. Sociologisk Forskning 55 (2-3): 365-387.

Suarez, D. 2011. Collaboration and Professionalization: The Contours of Public Sector Funding for Nonprofit Organizations. Journal of Public Administration Research and Theory 21(2): 307-326.

Timmermans, A. 2015. The moving stages of public affairs in the Netherlands. Interest Groups \&amp; Advocacy 4 (1): 25-39.

Trapp, N., and B. Laursen. 2017. Inside out: Interest groups' 'outside' media work as a means to manage 'inside' lobbying efforts and relationships with politicians. Interest Groups \&amp; Advocacy 6 (2): 143-160.

Tyllström, A. 2013. Legitimacy for Sale: Constructing a Market for PR Consultancy. Doctoral dissertation. Uppsala: Uppsala universitet.

Tyllström, A. 2019. More than a revolving door: Corporate lobbying and the socialization of institutional carriers. Organization Studies. https://doi.org/10.1177/0170840619848014.

Uhlin, A. 2010. The structure and culture of post-communist civil society in Latvia. Europe-Asia Studies 62 (5): 829-852.

Ullström, A. 2011. Styrning bakom kulisserna: Regeringskansliets politiska staber och regeringens styrningskapacitet. Doctoral dissertation. Stockholm: Stockholms universitet.

Van Wessel, M.G.J., D.J.M. Hilhorst, L.W.M. Schulpen, and C.H. Biekart. 2020. Government and civil society organizations: Close but comfortable? Lessons from creating the Dutch 'strategic partnerships for lobby and advocacy.' Development Policy Review 38 (6): 728-746.

Vogel, J., E. Amnå, I. Munch, and L. Häll. 2003. Föreningslivet i Sverige: Välfärd, socialt kapital och demokratiskola. Sociologisk Forskning 40 (2): 53-89.

von Essen, J. 2019. The shifting meanings of popular engagement in Swedish society. VOLUNTAS: International Journal of Voluntary and Nonprofit Organizations 30 (1): 29-40.

Weber, M. 1994. Political writings. Cambridge: Cambridge University Press.

Wilensky, H.L. 1956. Intellectuals in labor unions: Organizational pressures on professional roles. Glencoe, IL: Free Press.

Wilensky, H. 1964. The professionalization of everyone? American Journal of Sociology 70 (2): 137-158.

Publisher's Note Springer Nature remains neutral with regard to jurisdictional claims in published maps and institutional affiliations. 